\title{
Research on the Image Understanding of Internet Multimedia Technology in Modern Art Theory Teaching
}

\author{
Zi Wang ${ }^{1, a}$ \\ ${ }^{1}$ College of Fine Arts, Beihua University, 132013, Jilin City, China \\ azi_wang001@126.com
}

Keywords: Art theory teaching; Internet multimedia technology; Art theory development.

\begin{abstract}
. with the progress of science and technology, the audio tools were applied to art theory teaching in art theory teaching modernization. Internet multimedia technology has been applied in modern art theory teaching is very necessary. Application results show that the application of internet multimedia technology can snake the student snore easy to learn art theory, more easy to art theory development.
\end{abstract}

\section{Introduction}

As technology advances, people's standard of living getting higher and higher, then the tool is applied to the sound of art theory teaching, teaching in the modern art theory most cases, there will be the sound of participation, most of these are sound by sound from performing human voice or from some kind of art theory instrument, but for professional staff, they compare these sounds will have a similar requirement, that is, when the sound level and length are worth must be particularly accurate, so to grasp these vocal approach, professional art theories and learners must pay a lot of time to study, among a few people who will be away from art theory because of this reason. For this reason, with advances in computer technology, internet multimedia technology with the born, internet multimedia technology to solve the above problems have very good results, so use internet multimedia technology in modern art theory education is very necessary, internet multimedia technology It can make it easier for students to learn art theory, easier to professional art theory level of development after application.

For a long time, the traditional model of art theory education is "teachers teach, students learn," is the teacher as the main classroom, students passive learning, to a certain extent, confined students' imagination, creativity development. However, with the "student-centered" teaching philosophy of the new generation, the students become the subject of teaching, classroom teacher as the leading, its status and role changes, which requires teachers to build awareness of just as a student subsidiary, its helpful and facilitating role.

How to assist students who become teachers placed in front of an important issue, with the rapid development of computer technology, mankind has entered the information age, a variety of computer applications software, professional software into the our lives, but also a new generation of high school students cognitive activity in a very important aspect, which requires teachers to keep up the pace, so the times, to quickly grasp a variety of advanced electronic information technology, its application to everyday education activities, information tools in many, internet multimedia is one of learning for art theory, art theory experience and art theory activities are very important one.

\section{Multimedia assisted teaching}

In the current art theory teaching in primary and secondary schools, the use of computer-assisted instruction has two aspects, one multimedia assisted teaching, which is the use of multimedia courseware assisted teaching; the second is the use of computer software to art theory teaching, which is the work of a variety of internet multimedia software to assist teaching.

The term "internet multimedia" is from the art theory instrument digital interface (Art theory Instrument Digital Interface) abbreviation. It is an application of computer multimedia technology in 
the audio field. Entire internet multimedia system is including synthesizers, computer art theory software, audio, computers, internet multimedia connections, mixers, digital recorders and other peripheral devices. The computer can be derived from a keyboard instrument or other internet multimedia instruments produce sound information into digital information into the computer.

"Art theory curriculum standards," pointed out: "By providing an open and entertaining art theory learning scenarios to stimulate students' curiosity and desire to explore art theory, and guide students to impromptu free play as the main features of inquiry and creativity, attention to development students explore the process of creative thinking. "The internet multimedia technology into art theory teaching can greatly improve classroom teaching interesting; create art theory learning scenarios to stimulate students' curiosity about the world of art theory and the desire to explore, to guide students to use the computer network resources and internet multimedia technology impromptu free play of inquiry and creativity. In teaching, each student can share the authoring software, make full use of the resources provided by the instructor, who have learned to use art theory knowledge, give full play to their imagination and creativity, creation of art theory works. The conventional art theory teaching mostly on paper, has been repeated on the radio theoretical knowledge, this is obviously a great impact on teaching effectiveness, to a large extent influence the development of students' creative ability. But after using internet multimedia technology and multimedia technology, the effect of using these two techniques compatible assisted instruction on much better than traditional teaching effect, internet multimedia file in teaching-related applications, and through audio, synthesizer, audio peripherals, etc.

\section{Internet multimedia application in teaching}

First, the traditional teaching of singing lessons, teachers rely mainly on piano accompaniment and supporting materials to the accompaniment of song accompaniment recordings for students, which would likely generate the following situations:

Use the piano for the students to learn to sing the song accompaniment, speed is not easy to grasp was so accurate, are often sing again a kind of situation, even a sense of rhythm, the sense of speed is also very good teacher is very difficult to accurately labeled in accordance with the speed of the song They were playing. Art theory teacher of piano playing level everyone is not the same, some high piano teacher skills, can follow the original teaching reference spectrum accompaniment to play on, but once Professor songs are not original spectrum accompaniment, or students when you need to transpose learning to play concerts process, with a teacher's performance there will be two editions of bias, and some may even be "a big difference", not to mention those with poor skills piano teacher. Use accompaniment for students, it is hard to accurately control the recording time to start playing and stop time, once the student error or pause in the singing process, teachers will find just pause again Juana place continued to sing the song,

When using the traditional accompaniment for the students singing accompaniment, song tone number is extremely difficult to change, even if some of the recorder or player with ascending, descending tone function, often accompanied by the recording speed changes occur at the same time, not faster is slower, so that teachers who really headache ah. Some teachers proficient Piano Improvisation in classroom activities, regardless of what kind of change the song key signatures can come in handy, blossoms so, but the mood of the song performance will not help give students often command a bit to more good to mobilize students' emotion, this time we will see a hand piano teacher, one hand waving in the air, the students inside the ear to hear only the left-hand bass piano accompaniment, to think of it is "unique flavor." The above circumstances I believe that teachers in the teaching activities have ever met, but also in the traditional teaching activities can not be avoided, but now it is different, we will internet multimedia device is introduced into the teaching activities, these problems would be solved. 


\section{The role of technology in modern internet multimedia art theory teaching}

In the teaching of art theory, the art theory of this preparation should be and teaching other subjects are not the same, but the current situation is still the case, still, like other subjects, like a textbook, a lesson plan, a box of chalk, a piano. Only occasionally, when teachers will use computer-assisted instruction to enrich teaching art theory, but even computer-assisted instruction or teacher notes are written on the blackboard in a variety of characters, or put something on the books originally projected onto the blackboard so traditional Teaching is not much difference. Workers are use internet multimedia Engineering Technology lesson is what Nick? Teachers can repeatedly song, audition song, song accompaniment, listening links art theory, choral song links, notes, etc. all use to learn art theory sound, made into a file format internet multimedia workers, and these files in class when casually displayed based on the needs of teaching can be done "as long as you need, he can do it 'evening this effect, such as, art thermal ensemble, you can easily put a certain part of the sound, whether it is the tone of this file, speed, range, and so on classroom presentation and use. internet multimedia work out innovative internet multimedia technology has greatly improved from art theory the effect of teaching; this is updating the art theory teaching in the true sense.

Teaching art theory courses of professional composer as a teaching tool and is affected by the restrictions, the students and with the creation of art theory works when you want to achieve the effect of ordinary orchestra is very difficult. Therefore, in the conventional art theory teaching mostly on paper, has been repeated on the radio theoretical knowledge, this is obviously a great impact on teaching effectiveness, to a large extent influence the development of students' creative ability. But after using internet multimedia technology and multimedia technology, the effect of using these two techniques compatible assisted instruction on much better than traditional teaching effect, internet multimedia file in teaching-related applications, and through audio, synthesizer, audio peripherals, etc. equipment convey high-quality audio information, so that students in the process of playing the feeling is very real, and the use of internet multimedia technology side of the sheet art theory while listening to the effect of modification, it is easy to develop students' creativity.

Faced with an emergency during the class is a normal phenomenon, no matter what class will encounter in the classroom incident, which requires mastery of wit teachers teaching higher. In art theory teaching, such as learning to sing songs, in one place encountered rhythm or other reasons, when there is no solution, then you can use internet multimedia technology shift function, the playback speed to slow down, let students repeated simulation and audition. For example, a student in learning songs, original songs set the tone for students to sing it very difficult, but they did not do demotion teacher preparation, this time we can use internet multimedia technology demotion feature to pitch songs automatically reduces, but before doing these teachers will only need to be stored in memory in internet multimedia file internet multimedia file certain good, to prepare for contingencies.

The modern teaching technology and multimedia technology can make teaching better and more scientific work is completed, to strengthen teachers' training in multimedia devices, and has a very important role in the modernization of teaching. Work through the use of M DI technology, even large symphony orchestra "playing 'evening and a new audition works can be completed, you can work directly with the M D work art real-time recording function, its insertion recording, as well as many step recording, a variety of methods, in order to put the overall sound spectrum in accordance with the technical requirements of all its art theory into the computer inside, and get them ready for unified deployment and a unified command, and then use the "Computer tuning Taiwan 'evening to adjust the orientation of the sound, and the sound of the azimuth check, ask each part volume balance, sound level depth, comprehensive data arrangements. Finally, use a laser printer to print the score, this produced a fine quality of the score has been completely and almost professional printing. The use of traditional teaching methods in modern teaching methods and modern teaching technology, teaching content constantly enriched, so that students learn together very good initiative, but also in the process of learning to better grasp the various aspects of knowledge , so that the overall cultural quality of students has a positive effect. 
When we put internet multimedia art theory software into the teaching, the students can sit in the engine room, put on headphones creation quietly on the composer, will note written on the computer, play, edit, re-listen. It all seems so easy, so directly involved in traditional art theory teaching that can not understand that, for example, "TT composer", "Band in Books" and other composer, students not only can any writing at the top of his mind The melody, the software can also be coupled with a variety of styles on their own type of melody accompaniment, which greatly enhance the students' interest in learning, and truly become the subject of learning, some students in the classroom for their favorite art theory has allocated their own style of accompaniment, some students on the computer class created its own class songs, and some students use the art theory software has allocated truly their own cell phone ring tones, art theory and even some students thus had a strong interest in out of school after the singer became a minor celebrity in the network, the art theory of people. In short, multimedia internet multimedia technology in modern art theory education, a method and means more than just art reform, it should become a new teaching ideas and ways of thinking, in the whole society to promote quality education today, this Species teaching ideas and ways of thinking and will inject fresh blood for our art theory education, resulting in the role and significance immeasurable.

\section{Summary}

To sum up, we can see modern technology and modern teaching media play an important and irreplaceable for internet multimedia technology in modern art theory education professional teaching, not only has a better use of technology in art theory course, still audition drill has a better ability to use the application in art theory appreciation teaching is a strong feature. Through real practical teaching can know internet multimedia technology in modern art theory teaching has a very large potential applications of computer technology and will continue to update and develop in the future, this technology will certainly make art theory teaching occurs relatively large Variety.

\section{References}

[1] Kekang information technology and curriculum deep integration theory and method. art research. 2005 (0internet multimedia)

[2] Jiaoyao Guang basic education curriculum reform in the information technology and curriculum integration: problems and countermeasures. art Research 2004 (internet multimedia2).

[3] Wang Li. Application of Multimedia carry art theory teaching to improve teaching effectiveness . Primary and Secondary audio-visual. 2004 (internet multimedia2)

[4] Song Jin. In the aesthetic core of art theory education reform . Central Conservatory of Art theory. $2004(04)$

[5] Yao Xiaohui, Wang recorded. Rational Thinking of Information Technology and Curriculum Integration . Primary and Secondary audio-visual. 2004 (internet multimediainternet multimedia)

[6] Chen Weidong, Limang teachers of information technology and curriculum integration training design . Vocational and Technical Education. 2004 (07) [7] Wucai Juan Modern Art Technology in Art theory Teaching. Primary and Secondary audio-visual. 2004 ( Ointernet multimedia)

[7] Sun Taifeng Application information technology in art theory education. Changchun Normal University. 2003 (02)

[8] Zhang mirror. Multimedia applications in art theory education . Henan Vocational and Technical Teachers College. 2003 (0internet multimedia)

[9] Xia Lisheng Comparison and thinking of digital multimedia art theory education and traditional art theory education . China Art Technology. 2002 (internet multimediainternet multimedia) 